\title{
Aranguren no es un avión ni un pájaro
}

\author{
AMANDO DE MIGUEL
}

No es Aranguren propiamente un sociólogo, al menos un sociólogo empírico. Tampoco podría pasar por un canónico representante de lo que pomposamente se llama Teoría Sociológica. Pcro sospecho que un teólogo negaría a Aranguren la calidad de su preocupación por la materia religiosa. Puede que hicieran lo mismo los moralistas o los filósofos si planteáramos que Aranguren se dedicó a sus respectivas disciplinas. Este argumento de intrigantes negaciones me recuerda la cantinela de la historieta famosa: «iEs un avión? No. ¿Es un pájaro? No. iEs Supermán!» Y perdón por el comparando, tan irreverente, pero tan apropiado. Es decir, Aranguren es una personalidad un tanto proteica, difícilmente clasificable con las etiquetas académicas al uso. Yo, francamente, como sociólogo, lo veo más como un filósofo, pero seguro que los filósofos lo consideran más bien un moralista, y así hasta cerrar la cadena. Ni siquiera se puede decir que nuestro hombre empezara con uno de esos papeles y fuera evolucionando hacia los otros. El primer Aranguren es ya tan heterodoxo o tan personal como el último. Los cambios fueron cosméticos. En el bien entendido que él hubiera advertido que lo cosmético es una variante de lo cósmico, esto es, lo que busca la coherencia en medio del caos.

Esta secuencia «borrosa» de ser lo que no es nos lleva al modo circular y paradójico de razonar que tanto placía a Unamuno. Con el de Salamanca, Aranguren mantiene muchos puntos de contacto, como el gusto por la paradoja, el placer de la etimología o la angustia religiosa. Ambos fueron, ante todo, intelectuales de una pieza. No olvidemos que fue Unamuno quien utilizó por primera vez en el mundo el sustantivo «intelectual» (en 1896, dos años antes de lo de Zola), desde luego aplicado a sí mismo. Unamuno fue, primero, catedrático de Griego. Esta forzada dedicación (perdió la cátedra de Vascuence y no se había convocado la de Filosofía) hizo que sus escritos destilaran luego los juegos etimológicos a los que tan aficionado era. No es por un capricho, ni un juego. Es una convicción de que el origen de las cosas explica mucho del verdadero sentido de esas cosas. Por cierto, ése es el fundamento del sentido formativo que tiene el conocimiento de la cultura clásica. El accidente de la cátedra de Griego va a ser definitivo en la carrera de Unamuno. Algo así le ocurre a Aranguren. Saca una cátedra de Ética y Sociología, denominación tradicional en la línea de las Ciencias Morales y Políticas de la tradición francesa. Investido con título tan rimbombante, no le queda más remedio que ser fiel al marbete académico. Así, va tiñendo con el colorante sociológico sus escritos de Filosofía Moral, de Moral Filosófica o como se quieran llamar. Lo cual le obliga a cscudriñar los saberes sociológicos, primero alemanes, luego nor- 
teamericanos. Ante todo, lo suyo -igual que en Unamuno o en Ortegafue un estilo y un ejemplo personal de firme independencia. Ambos tuvieron, como Sócrates, una misión deletérea respecto a ciertas convenciones políticas de su respectiva época. Los tres sobresalieron en el arte suasorio, que encandilaba a los jóvenes, y por eso irritaron a lo que podríamos llamar el Establecimiento que a cada uno le tocó en su día y en su ambiente. Tanto Sócrates como Unamuno, Ortega y Aranguren conocieron el ostracismo, la pena mayor para un maestro. Aranguren disfrutó al final de un gran reconocimiento.

Al hilo de lo que digo, recuerdo que me tocó comer con Aranguren el mismo día en que se casaba su buen amigo Jesús Aguirre. Así que nuestro hombre se perdió el mundano festejo. No se imaginaba vestido de chaqué. Me parece que aquella mañana habíamos participado en una tenida de la Escuela de Diseño Textil de Barcelona, donde ambos éramos algo así como profesores visitantes y honoríficos. El almuerzo, mano a mano, en la Bonanova, mereció una larga sobremesa. Naturalmente hablamos del duque de Alba como símbolo del Establecimiento. El profesor tenía que haber estado en la boda, pero no podía estar. Ahí pude ver lo increíblemente reacio que era José Luis a cualquier forma de vanidad, de ostentación. No iba a perderse él un coloquio en la Escuela de Diseño Textil por cl aristocrático bodorrio. Me percaté, además, de que a nuestro filósofo (o moralista o lo que fuera) se le podía conocer poco por sus escritos, y mucho escuchándole. Era un mago de la mayéutica. Llevaba el auditorio donde él quería. Al igual que Simmel y que Ortega, su público más enfervorizado era el femenino. Y sin embargo no se puede decir que los tres personajes citados fueron apóstoles del feminismo.

La obra entera de Aranguren es un discurrir sobre la sociedad actual, a la que sabe «desmoralizada» sin remedio. Este pesimismo metódico es también muy unamuniano. Su estilo de análisis sociológico se parece mucho al discurrir fenomenológico de Jorge Simmel o de Max Scheler. Por eso se fija tanto en muchos aspectos de la vida cotidiana, que son los que tentaron a esos dos maestros alemanes. Precisamente, una larga conversación que tuve yo con él y con Juan J. Linz me orientó sobre el asunto de la lección magistral de mi primera oposición a cátedra, naturalmente fallida. Pero ahí quedó la lección en forma de librito. Era una perspectiva inédita para mí. (Como saben los profesores, esa táctica de elegir una lección magistral alejada de lo que uno ha investigado es la que se aconseja a la hora de «sorprender» al tribunal con una.) Desde entonces le he cogido cariño. Aunque «lo mío» sea más bien la investigación con porcentajes, de vez en cuando vuelvo a ese otro ameno prado de la sociología (cualitativa o literaria) de la vida cotidiana. Ahora se entenderá lo de la mayéutica de Aranguren. Gracias a su consejo e influencia, muchos investigadores desarrollaron sus respectivos trabajos de la más variada índole. Esto es lo que quiere decir la palabra «maestro».

Otro punto que me acerca a la manera de ver la sociedad que tiene nuestro hombre es el papel central que le concede a la religión. Yo también la veo 
como una parte del paisaje más amplio de los valores, de la moral en el sentido de las mores. El libro Catolicismo y protestantismo lo leí de un tirón en primero de carrera. Me dejó patidifuso. Se puede uno imaginar lo que yo sabía entonces sobre el protestantismo. Creo que desde esa lectura se me quedó dentro el acicate de que yo tenía que escribir un libro como aquél. Puesto que todavía no he podido satisfacer esa urgencia, sigo escribiendo. Cuidado que le habré dado vueltas al capítulo de la religión y los valores. Aquí está la clave de lo que nos pasa. Lo digo por si alguien más quiere seguir desentrañando el enigma.

No sólo la religión. Hay otros aspectos de la estructura social que a mí me han cautivado y que ahora pienso que fueron tratados con mimo por Aranguren. Por ejemplo, los jóvenes, la mujer, la moda, la familia, la Universidad, el lenguaje, los intelectuales. Sólo hay una divergencia notable. A mí no logró nunca interesarme el marxismo, y eso que me apresté a deglutir los textos oficiales de Marx y Lenin durante mis años de estudiante. No hubo manera. Reconozco que en esto Aranguren fue más juvenil que yo mismo, en el sentido de que palpitó más con las preocupaciones y las modas vigentes en mi época estudiantil.

Para Aranguren, los cultivadores de las ciencias sociales tienen por fuerza que asumir la función intelectual. Ésta consiste en criticar la «desmoralización de nuestro tiempo». Es una prolongación del programa regeneracionista o de las inquietudes de los hombres del 98, pasando luego por Ortega. Es extraordinaria la continuidad del estilo o talante a lo largo de esa tradición de casi un siglo. Se apoya sobre un gran desasosiego con el mundo que les ha tocado vivir. Aquí es donde entra la estupenda definición de intelectual que da Aranguren. Es un lúcido reconocimiento de lo que fue su actitud ante la vida: «Es intelectual el que, ante todo, sabe escuchar lo que no se ha dicho, oír lo que se siente $y$, por ello, $y$, tras ello, puede pronunciar la palabra que muchos buscaban, sin acabar de encontrarla.» Para llegar al dominio de esas cualidades no hay ningún secreto taumatúrgico. De forma muy modesta, el intelectual es «quien asume a modo de oficio, para toda la vida, y no, según es común, durante los años de estudiante, el aprender» (Talante, juventud y moral, Ediciones Paulinas, 1975, p. 314). El aprendizaje incesante lleva a Aranguren a estar siempre al día, a importar lo que se lleva en diversos campos y países. Esto es también muy unamuniano y luego orteguiano. Al igual que sus antecesores, Aranguren abomina la complejidad de la sociedad moderna, sus aspectos materiales. Le disgusta el «bárbaro especialista» que criticaba Ortega, pero sobre todo le molesta el consumismo. Es otra forma de plantearse la desazón que produce la «rebelión de las masas». También es curioso que le obsesionaran tanto a Aranguren los excesos del consumo. Él no fue precisamente un asceta. Llevó una vida acomodada y hasta refinada. Se refería algunas veces a sus aficiones automovilísticas cuando jovencito. Pero el disgusto que le produce a Aranguren la sociedad de consumo no es por lo material, 
sino por lo moral, claro está. Le encocora la falsedad de la moral vigente, que busca el "pseudohedonismo de la diversión ajetreada, azacanada y manipulada, que ha desplazado el acento del sentido de la vida desde el tiempo del trabajo al tiempo pseudolibre del consumo por el consumo, como símbolo de status o ilusión de bienestan (Sobre imagen, identidad y heterodoxia, Taurus, 1982, p. 168). Sospecho que nunca logró asimilar el modo de vida californiano.

Durante mucho tiempo la imagen de Aranguren como intelectual se asoció a la de Tierno Galván. Sin embargo, eran dos mentalidades divergentes. Coincidieron por la circunstancia fortuita de la oposición al franquismo. Pero luego se vio que Tierno - como otros muchos intelectuales - realmente estaba haciendo carrera política. La cual nunca atrajo a Aranguren. De ahí que, ya en la transición, asegure que «no se puede ser intelectual de derechas» y casi tampoco si se es de izquierdas (La función social del intelectual, Ayuso, 1983, p. 43). Venía a significar la exigencia de que el verdadero intelectual tenía que ser independiente de los partidos políticos. Creo que es una exigencia desmesurada, pero, en fin, lo que yo piense ahora es lo de menos. La sustancia del asunto es que Aranguren no compartía la noción de «intelectual orgánico» que tanto atraía a la izquierda.

Veo que estas reflexiones mias me han salido más cálidas y personales de lo que hubiera sido menester según ordenan las costumbres académicas. Pero es tarde para enmendarme. Escribo a mano, y lo que antecede ha sido como un desahogo que me ha salido de corrido. Luego lo he pulido, pero casi siempre añadiendo más impresiones personales. Se me perdonará tanta primera persona. Seguramente, sin quererlo, estas páginas son la respuesta al inmenso piropo que me dirigió Aranguren cuando estampó: «Me gustaría llamarme y ser Amando» (Sobre imagen..., p. 185). iVaya un epigrama afectivo! Quería decir realmente José Luis, recogiendo una crítica mía, que él lo que más ambicionaba «sobre todas las cosas era ser amadon. En esto sí que coincidimos, sea cual sea nuestro respectivo nombre, que es de las pocas cosas nuestras que realmente no lo son. Sólo que, con el paso del tiempo, el nombre de uno es cada vez más su obra. Aranguren es hijo de la suya, como todos. La obra escrita en su caso, pero, descle mi recuerdo, más aún su palabra, su conversación. Daba una charla de una hora larga con sólo una uchuletita» delante, a la cual, además, ni siquiera miraba. Su voz era tan tenue, su aire tan desmadejado, que provocaba como un desvalimiento de su figura. Todo llevaba a la atención silenciosa por parte de la concurrencia. Estamos, pues, ante un gran actor. Sería una estúpida reverencia no reconocerle esa rara cualidad, que todos los profesores desean y tan pocos consiguen. Recuérdese que prestigio es una voz emparentada con prestidigitador. Me parece que este juego de palabras lo recordaban tanto Unamuno como Ortega y Aranguren. Los tres fueron prestigiosos profesores y prestidigitadores de las ideas, de las imágenes verbales. Los tres ocupan el mismo rincón de mi libreria. Seguramente disfrutan la misma estancia del cielo de los intelectuales. Al menos habrán podido vislumbrar desde ese lugar etérco que esta su España tampoco es que haya sido dejada de la mano de Dios. 